\title{
PROSES PEROLEHAN KOMPETENSI TIK MELALUI PROGRAM PRAKTIK INDUSTRI SISWA SMKN 2 PENGASIH KULON PROGO
}

\author{
Nuur Wachid Abdul Majid \\ PTK PPs \\ nuurwachid@gmail.com \\ Putu Sudira \\ Fakultas Teknik Universitas Negeri Yogyakarta \\ putupanji@uny.ac.id
}

\begin{abstract}
Abstrak
Penelitian ini bertujuan untuk menemukan: (1) proses perolehan kompetensi melalui program PI di DUDI; dan (2) hasil perolehan kompetensi siswa setelah mengikuti program PI di DUDI. Penelitian ini menggunakan pendekatan kualitatif jenis studi kasus. Setting penelitian ini adalah di PT. JMI sebagai industri pasangan SMKN 2 Pengasih. Informan pada penelitian ini adalah pimpinan atau pemilik PT JMI, pembimbing industri, pembimbing siswa dari sekolah, dan siswa peserta PI. Pengumpulan data melalui observasi, wawancara mendalam dan studi dokumentasi. Teknik analisis data mengacu pada analisis model interaktif Miles \& Huberman, meliputi pengumpulan data, data condensation, penyajian data, verifikasi, dan penarikan kesimpulan. Hasil penelitian ini menunjukkan bahwa proses perolehan kompetensi TIK dalam program PI melalui: (1) proses untuk memperoleh kompetensi di tempat industri, meliputi: (a) melalui pengamatan dan mendengarkan, (b) belajar sambil menyelesaikan tugas (learning by doing) dan mengikuti aktivitas kerja, (c) belajar melalui pengalaman, (d) belajar memecahkan masalah, $(e)$ belajar melalui kondisi lingkungan kerja, $(f)$ belajar mandiri, dan $(g)$ belajar secara terus menerus dan diulang-ulang; dan (2) hasil yang didapat siswa setelah mengikuti program PI adalah mampu menunjukkan perkembangan kognitif, afektif, dan psikomotorik yang dapat dideskripsikan antara lain: pengetahuan terkait dunia kerja, keterampilan kerja, kemampuan menyelesaikan pekerjaan, dan sikap yang berkaitan dengan DUDI.
\end{abstract}

Kata kunci: proses perolehan kompetensi, hasil perolehan kompetensi, Program PI, TIK

\section{THE ACQUISITION PROCESS OF ICT COMPETENCE THROUGH INDUSTRIAL PRACTICE PROGRAM OF THE STUDENTS OF SMKN 2 PENGASIH KULON PROGO}

\begin{abstract}
This research aims to investigate: (1) the acquisition process competency through industrial practice program in DUDI; and (2) students' acquisition outcomes in the industrial practice program. The research used the qualitative case study approach. This research took place at PT JMI as a partner of SMKN 2 Pengasih. The informants in this research were the owner PT. JMI, the industrial mentors, the school mentor, and students who participated in the industrial practice program. The data were collected through observations, in-depth interviews, and documentation. The technical analysis of the data refered to the analysis of Miles \& Huberman interactive model, including data collection, data condensation, data display, and drawing and verifying conclusions. The result shows that the process of acquisition of ICT competencies in the PI program is through: (1) process of acquiring competencies in the industry, including: (1) learning through observing and listening, (b) learning while completing the task (learning by doing) and work activities; (c) learning through experiences, (d) learning to solve problems, (e) learning through work environment, $(f)$ self-directed learning, and $(g)$ continuous and repeated learning; and (2) students' learning outcomes in the industrial practice program are able to demonstrate cognitive, affective, and psychomotor developments, including knowledge of the world of work, job skills, ability to finish the job, and attitudes related to DUDI.
\end{abstract}

Keywords: the acquisition process of competencies, the acquisition outcome of competencies, PI program, ICT 


\section{PENDAHULUAN}

Keterkaitan antara SMK dengan industri merupakan hal yang sangat penting karena tujuan akhir dari lulusan SMK adalah mampu bekerja sesuai keahlian kerja di industri. Menciptakan lulusan yang berkualitas dan mengurangi angka pengangguran harus didukung dengan kerja sama antara kedua belah pihak. SMK memanfaatkan DUDI sebagai tempat praktik dan difungsikan untuk menambah wawasan tentang DUDI kepada siswa. Melalui program kerja sama tersebut, maka permasalahan SMK dapat diminimalisir. Permasalahan SMK saat ini pada umumnya terkait dengan keterbatasan peralatan, masih rendahnya biaya praktik, dan lingkungan belajar yang tidak serupa dengan dunia kerja (Pardjono, 2011, p. 1). Pada dasarnya sekolah dan industri memiliki keterbatasan masingmasing dalam menyiapkan tenaga yang siap bekerja. Sekolah memiliki keterbatasan pada pembiayaan dan lingkungan dalam belajar, sedangkan industri memiliki keterbatasan pada tenaga pendidik dalam menyiapkan tenaga kerja yang dibutuhkan. Dengan demikian, upaya kerja sama dan keterlibatan DUDI untuk menyusun program pelatihan merupakan hal yang sangat penting.

Kerja sama antara sekolah dan DUDI dapat bermanfaat sebagai bagian dari proses pembentukan kompetensi. Selain itu kerja sama tersebut dapat menambah wawasan tentang dunia kerja kepada siswa. Penempatan praktik di DUDI dapat berfungsi sebagai: (1) tempat praktik siswa; (2) tempat magang siswa; dan (3) tempat belajar manajemen dan wawasan dunia kerja (Pardjono, 2011, p.3). Kegiatan siswa untuk membentuk kompetensi melalui observasi dan praktik langsung yang berkaitan cara kerja mesin, produk yang dihasilkan, manajemen industri, dll. Melalui kegiatan tersebut siswa dapat memiliki pengalaman, kompetensi, dan wawasan berkaitan dengan DUDI. Oleh karena itu, penyesuaian suasana tempat kerja merupakan salah satu cara untuk membentuk kompetensi peserta didik. Proses belajar di industri merupakan kondisi lingkungan kerja yang nyata. Kompetensi siswa dapat lebih cepat terbangun apabila kondisi lingkungan merupakan kondisi nyata ketika mereka bekerja.

Kompetensi peserta didik memerlukan bimbingan oleh para ahli agar dapat terarah.
Bimbingan sosial yang dilakukan oleh seseorang ahli atau yang sudah berpengalaman merupakan bagian dari proses perolehan kompetensi yang dilakukan oleh peserta didik. Melalui proses tersebut, peserta didik dapat mengambil segala keterampilan, pengetahuan, dan sikap yang diberikan atau dicontohkan. Pembentukan kompetensi di sekolah dan industri merupakan bagian dari link and match yang sudah digagas oleh Pemerintah.

Praktik Industri merupakan implementasi dari beberapa model sekolah kejuruan, khususnya model sistem ganda (dual system model). Model sistem ganda merupakan lanjutan link and match yang sudah digagas oleh Pemerintah. SMK menerapkan program sistem ganda agar dapat menyesuaikan kompetensi yang dibutuhkan oleh industri. Pengalaman yang diperoleh pada saat proses praktik industri (PI) secara tidak langsung menambah kompetensi siswa. Peningkatan pengalaman yang didapat merupakan bentuk dari ketercapaian kondisi transisi dari sekolah ke dunia industri. Keterlibatan DUDI sangatlah diperlukan dalam meningkatkan kualitas lulusan dan dapat menjembatani kesenjangan antara kompetensi yang dihasilkan sekolah dengan tuntutan DUDI. Maka dapat disimpulkan bahwa upaya peningkatan kualitas lulusan SMK merupakan tanggung jawab bersama antara SMK, industri (DUDI), dan masyarakat.

Program PI bermanfaat bagi SMK untuk memenuhi SKL yang sudah ditentukan. Program PI atau magang dapat membantu Pemerintah untuk mengurangi pengangguran, mempercepat penyerapan tenaga kerja di pasar kerja dan membuka wirausaha baru. Menteri Ketenagakerjaan, M. Hanif Dhakiri Dhakiri mengatakan bahwa Pemerintah mendorong program pemagangan sebagai program prioritas untuk mengurangi pengangguran, mempercepat penyerapan tenaga kerja di pasar kerja dan membuka wirausaha baru (Hardum, 2015). Selain itu Program PI atau magang dapat menjadi alternatif untuk mempersiapkan kualitas SDM menjelang Masyarakat Ekonomi ASEAN (MEA) 2015.

Program PI mendapat perhatian khusus dari Pemerintah untuk dikembangkan karena pentingnya penyelenggaraan program tersebut. Sebuah survei riset yang dilakukan oleh lembaga pemerintahan dan akademisi yang dilakukan pada bulan Juli sampai Agustus 2012 terungkap bahwa 88,97 \% peserta pela- 
tihan atau magang menyatakan puas terhadap pelayanan penyelenggaraan diklat (BBPP Batangkaluku, 2013). Hal ini didasarkan pada hasil analisis data tingkat kepuasan terhadap setiap indikator yang mempengaruhi kepuasan peserta terhadap pelayananan penyelenggaraan pelatihan. Hasil penelitian berkaitan dengan manfaat PI sangat besar dirasakan oleh siswa, sekolah, dan DUDI. Hal ini dapat dilihat dari hasil penelitian Suwarman \& Pardjono (2014, p. 94) yang menunjukkan bahwa: (1) skor rata-rata manfaat praktik kerja industri yang dirasakan oleh siswa sebesar 340,16 termasuk kategori sangat tinggi; (2) Skor rata-rata manfaat praktik kerja industri yang dirasakan sekolah sebesar 8,88 termasuk dalam kategori tinggi; dan (3) skor rata-rata manfaat praktik kerja industri yang dirasakan industri sebesar 57,5 termasuk dalam kategori tinggi. Selain itu Suwarman \& Pardjono (2014, p. 94) mengungkapkan bahwa proses praktik kerja industri menurut persepsi siswa, guru, dan pembimbing berjalan dengan baik. Dengan demikian proses pelaksanaan PI sangat baik dan memiliki manfaat yang sangat besar.

Kedua hasil studi di atas menunjukkan bahwa program PI atau magang memiliki manfaat yang sangat besar dan sudah berjalan dengan baik. Namun permasalahan yang muncul adalah kurangnya penelitian terkait dengan proses pembelajaran di DUDI, mengingat sebuah proses sangat berpengaruh terhadap ketercapaian atau hasil. Dengan demikian proses yang baik dan sesuai dengan prosedur akan menghasilkan sesuatu yang baik, begitu pula sebaliknya.

Kajian yang mendalam berkaitan dengan proses pembelajaran (learning process) di DUDI sangat penting dilakukan. Alasan ini berdasarkan pada permasalahan yang muncul dari perencanaan dan proses pelaksanaan PI, seperti: (1) pembagian tugas yang terlibat di DUDI; (2) sekolah belum menetapkan standar kualifikasi guru pembimbing praktik kerja industri (Suwarman \& Pardjono, 2014, p. 94); (3) PI belum memperoleh dukungan secara maksimal dari industri, karena kehadiran siswa praktik masih dinilai berdasarkan kebermanfaatannya dalam waktu pendek dari sudut ekonomi (Bukit, 2002, p. 532); (4) kehadiran siswa dalam prakerind masih menjadi beban bagi DUDI dan kekhawatiran DUDI akan resiko kegagalan hasil pekerjaan yang berarti rugi uang dan rusaknya reputasi masih tinggi (Miswardi \& Pardjono, 2013, p. 270). Berdasarkan permasalahan di atas, penyelenggaraan PI masih memiliki permasalahan dan harus segera dibenahi, serta menjadi tugas besar oleh semua pihak. Pelaksanaan PI harus dirancang dengan baik agar betul-betul efektif dalam pemenuhan SKL lulusan SMK. Dengan demikian proses pelaksanaan PI akan berjalan dengan baik apabila perencanaan program sudah betul-betul matang, sehingga hasil dari pelaksanaan PI akan sesuai dengan yang direncanakan atau berdampak positif.

Bidang TIK sangat diminati oleh banyak pihak agar dapat mempelajari dan mengembangkannya. Pengembangan TIK perlu didasari pada kebutuhuhan teknologi, dunia kerja, dan masyarakat agar tidak sia-sia didalam proses pembelajaran yang dilakukan. Agar kebutuhan tersebut dapat terwujud, proses pembelajaran yang dilakukan harus diamati secara mendalam melalui sebuah kajian penelitian. Mengingat masih sedikit penelitian berkaitan dengan proses pembelajaran (learning process) di DUDI pada bidang TIK. Penelitian ini diharapkan dapat meningkatkan lulusan TIK yang siap kerja, berwirausaha, dan dapat melanjutkan ke pendidikan tinggi.

Penelitian ini secara umum bertujuan untuk mengetahui proses perolehan kompetensi yang didapat siswa saat melakukan praktik industri. Secara khusus penelitian ini bertujuan untuk: (1) mengungkap proses belajar siswa untuk mendapatkan kompetensi melalui program PI di DUDI; (2) mengungkap hasil yang didapat siswa setelah mengikuti program PI di DUDI.

Pendidikan kejuruan yang efektif harus memperhitungkan pembentukan kompetensi siswa dan penerapannya. Menurut Catts, Falk, \& Wallace (2011, p. 7) "We contend that effective vocational learning comprises two equally important dimensions: (a) learning as the acquisition of vocational knowledge and (b) learning as the contextualized (socio-political and cultural) application of that knowledge". Pembelajaran pendidikan kejuruan yang efektif terdiri dari dua dimensi yang sangat penting, yaitu: (a) belajar sebagai perolehan pengetahuan kejuruan; dan (b) belajar secara kontekstual (sosial-politik dan budaya) dalam penerapan pengetahuan tersebut. Pembelajaran pendidikan kejuruan dapat efektif apabila proses pendidikan menggunakan kon- 
sep social partnerships. Konsep ini membutuhkan kerja sama antara dan melibatkan komunitas, para pekerja, dan situasi di tempat kerja. Dengan demikian, pembentukan kompetensi siswa dan penerapannya dapat tercapai melalui konsep social partnerships, serta kompetensi yang diperoleh dapat diterapkan secara kontekstual.

Konsep social partnership menghasilkan kompetensi baru yang didapat oleh seseorang bersama komunitasnya. Wallace (2011, p. 12) berpendapat bahwa konsep sosial dan situated learning dibangun berdasarkan pada seseorang memperoleh pengetahuan dan keterampilan baru, serta mengasilkan konstruksi melalui partisipasi dalam praktik bersama komunitasnya. Pembelajaran di industri merupakan penerapan dari konsep social partnership dan situated learning.

Perubahan paradigma pendidikan kejuruan diimplementasikan dengan suatu model yang sering disebut Pendidikan Sistem Ganda (PSG). Djojonegoro (1998) berpendapat bahwa PSG pada dasarnya mengandung dua prinsip utama, yaitu: (1) Program pendidikan kejuruan pada SMK adalah program bersama (joint program) antara SMK dengan industri/ perusahaan pasangannya; dan (2) program pendidikan kejuruan dilakukan di dua tempat, sebagian program yaitu teori dan praktik dasar kejuruan dilaksanakan di SMK, dan sebagaian lainnya dilaksanakan di dunia kerja, yaitu keahlian produktif yang diperoleh melalui kegiatan bekerja di dunia kerja.

Praktik Industri (PI) merupakan bagian dari program sistem ganda (PSG) di SMK. Hal ini dapat terbukti dengan kesamaan prinsip diantara keduanya. PI merupakan komponen wajib yang harus dipenuhi oleh siswa SMK agar mendapatkan kompetensi yang sesuai. Perolehan kompetensi tersebut membutuhkan bimbingan oleh karyawan yang hali agar pemenuhannya sesuai dengan target yang sudah direncanakan.

Karyawan membimbing siswa membutuhkan proses yang terus menerus. Ketercapaian kompetensi membutuhkan pekerjaan yang terus menerus melalui pengalaman di lingkungan kerja. Shariff \& Muhamad (2010, p. 1362) mengatakan bahwa Siswa mengikuti program magang mendapatkan peningkatan hasil pembelajaran yang signifikan, peningkatan keterampilan komunikasi dan peningkatan personal secara signifikan. Dengan de- mikian, melalui PI tersebut siswa mengalami peningkatan kompetensi yang signifikan.

PI dapat digunakan sebagai tempat belajar pada aspek budaya dan sosial. Proses pembelajaran membutuhkan perpaduan dengan jaringan sosial yang sering diabaikan (Singh, 2009, p. 352). Hal ini mengakibatkan terjadinya perbedaan penerapan kompetensi yang dimiliki. Penerapan kompetensi pada setiap daerah sangat berbeda dengan daerah lain. Oleh karena itu siswa dituntut untuk mempelajari kompetensi pada aspek sosialbudaya ditempat kerja (Majid, 2015).

Budaya kerja dapat digunakan sebagai metode KBM. KBM praktik diarahkan pada kondisi kerja atau produksi di Industri. Prinsip yang digunakan adalah efektif dan efisien secara ketat yang mana hanyahanya dua kondisi hasil kerja, yaitu diterima atau ditolak (Muliati, 2008, p. 13). Siswa harus berusaha secara maksimal untuk mengikuti budaya kerja tersebut. Dengan demikian siswa dapat melakukan beberapa metode untuk mendapatkan kompetensi tersebut berdasarkan budaya kerja yang ada di DUDI.

Pertanyaan penelitian yang harus mendapatkan jawaban pada penelitian ini adalah: (1) kompetensi apa saja yang dibutuhkan DUDI untuk menerima siswa PI?; (2) bagaimana kegiatan siswa saat PI?; (3) bagaimana pola pembimbingan yang dilakukan oleh pembimbing PI?; (4) bagaimana cara mendapatkan kompetensi saat praktik?; (5) Kompetensi apa saja yang didapat setelah PI?; dan (6) bagaimana bentuk evaluasi untuk mengukur peningkatan kompetensi siswa?

\section{METODE PENELITIAN}

Penelitian studi kasus cocok digunakan untuk menyelidiki proses perolehan kompetensi TIK saat PI dan berusaha menemukan makna dari individu maupun situasi tersebut. Menurut Emzir (2010, p. 20) mengemukakan bahwa penelitian studi kasus merupakan penelitian kualitatif yang berusaha menemukan makna, menyelidiki proses, dan memperoleh pengertian dan pemahaman yang mendalam dari individu, kelompok, atau situasi. Dengan demikian pemilihan pendekatan studi kasus dalam penelitian kualitatif ini sangat tepat untuk mengungkap proses perolehan kompetensi TIK saat PI. 
Penelitian ini berlokasi di SMKN 2 Pengasih yang beralamat di jalan KRT. Kertodiningrat, Pengasih, Kulon Progo, Daerah Istimewa Yogyakarta. Selain di SMKN 2 Pengasih, penelitian dilakukan di PT. Jaringan Multimedia Indonesia (PT. JMI) sebagai industri pasangan SMKN 2 Pengasih. Adapun waktu penelitian ini dilaksanakan selama 6 bulan yaitu terhitung bulan Oktober 2014 sampai bulan Maret 2015 dengan cara peneliti terlebih dahulu melakukan pendekatan informan (subjek penelitian), menentukan responden, membangkitkan data, menganalisis data, dan yang terakhir adalah menulis laporan penelitian.

Unit analisis pada penelitian ini adalah proses perolehan kompetensi TIK dalam program PI di PT JMI. Penentuan unit analisis didasarkan pada pertimbangan obyektif untuk mengungkap proses perolehan kompetensi TIK dalam program PI di PT JMI.

Informan ditentukan atas pertimbangan tujuan penelitian dengan kriteria jaringan informan. Pemilihan informan diharapkan benar-benar menguasai topik atau situasi yang diteliti. Informan kunci pada penelitian ini yaitu: (1) Pimpinan atau pemilik DUDI; (2) Pembimbing siswa dari DUDI; (3) Pembimbing siswa dari Sekolah; dan (4) Siswa Kelas XII SMKN 2 Pengasih.

Teknik pengumpulan data dibagi menjadi tiga bagian, yaitu: pra penelitian, proses penelitian, dan pasca penelitian. Pengumpulan data dalam penelitian ini menggunakan teknik: (1) wawancara mendalam (in-depth interview); (2) observasi partisipatif; dan (3) analisis dokumen dari sumber-sumber data yang terkait dengan pertanyaan penelitian. Dalam proses pengumpulan data tersebut dilakukan secara alami (nature) sebagai bagian dari proses perolehan kompetensi pada PI. Analisis data dilakukan dalam dua kategori yaitu: analisis data selama di lapangan dan analisis data sesudah meninggalkan lapangan. Peneliti menggunakan model interaktif untuk menggali data secara terus menerus, berlanjut, dan berulang-ulang. Dengan demikian analisis data kualitatif dilakukan secara terus menerus, berlanjut, dan berulang-ulang sampai menghasilkan kejenuhan data. Berikut adalah analisis data menggunakan model interaktif dari Miles, Huberman, \& Saldana (2014) seperti Gambar 1.

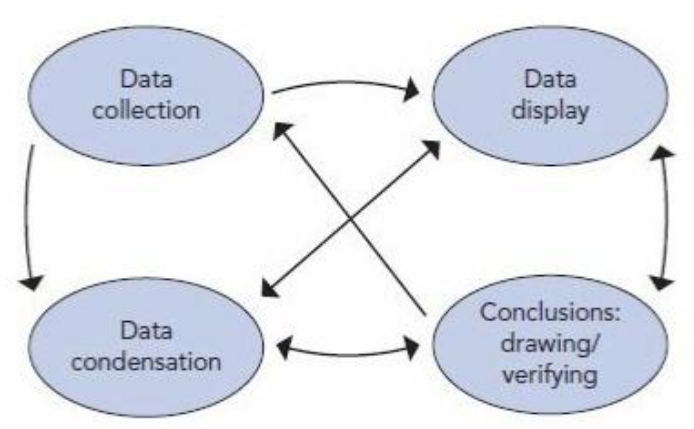

(Sumber: Miles et al., 2014, p. 10)

Gambar 1. Komponen-Komponen analisis data: Model Interaktif

\section{HASIL PENELITIAN DAN PEMBAHASAN}

Penempatan DUDI sebagai tempat belajar merupakan cara yang efektif. Siswa dapat mengetahui beberapa hal yang belum diajarkan di sekolah, terutama pada bagian praktis di lapangan. PI menggambarkan suasana kerja secara nyata kepada siswa berkaitan dengan DUDI. Pada akhirnya siswa dapat mengkolaborasikan ilmu yang didapat dari sekolah dan industri.

PI dapat digunakan sebagai tempat belajar pada aspek budaya dan sosial. Proses pembelajaran membutuhkan perpaduan kedua aspek tersebut. Hal ini mengakibatkan terjadinya perbedaan penerapan kompetensi yang dimiliki pada setiap daerah. Penerapan kompetensi pada setiap daerah sangat berbeda dengan daerah lain. Oleh karena itu siswa dituntut untuk mempelajari kompetensi pada aspek sosial-budaya ditempat kerja.

Siswa dapat meraih sukses dengan memiliki employability skills. Employability skill memerlukan banyak keterampilan yang siap dalam berkarir, kemampuan kerja keterampilan, keahlian teknis dan pengetahuan akademis. Kemampuan tersebut tidak dapat diperoleh dengan cara instan, melainkan membutuhkan sebuah proses yang sangat panjang. Selain itu, employability skills dapat diperoleh melalui program PI tersebut apabila siswa bersungguh-sungguh mengikuti kegiatan dengan tekun dan sesuai aturan yang berlaku.

Program keahlian atau Paket Keahlian TKJ bertujuan untuk mencetak lulusan yang ahli dibidang teknik komputer dan jaringan. Untuk mewujudkan tujuan tersebut, siswa harus belajar di DUDI yang fokus bergerak pada bidang komputer dan jaringan. 
Penyelenggaraan pendidikan di SMK mengacu pada tiga aspek kompetensi, yaitu: (1) adaptif; (2) normatif; dan (3) produktif. Kompetensi adaptif dikembangkan melalui mata pelajaran yang mengandung nilai verbal, numerik, dan adaptabilitas, seperti: Matematika, Fisika, Bahasa, dll. Kompetensi normatif dikembangkan melalui mata pelajaran yang mengandung nilai-nilai norma, seperti: Agama, Pendidikan Kewarganegaraan, dll. Kompetensi produktif dikembangkan melalui pembelajaran pada mata diklat sesuai dengan disiplin ilmu yang dipilih untuk membekali siswa agar memiliki kompetensi sesuai SKKNI yang ditetapkan Pemerintah.

Pembelajaran produktif merupakan bagian yang penting untuk meningkatkan keterampilan keahlian siswa. Pembelajaran produktif memiliki dua ciri pokok, yaitu pembelajaran berbasis kompetensi (competencybased learning) dan berbasis proyek (projectbased learning). Pembelajaran berbasis kompetensi mengacu kepada kompetensi yang telah di rencanakan antara SMK dan DUDI. Sedangkan pembelajaran berbasis proyek mengacu kepada prosedur dan standar kerja yang sesungguhnya (real job) sesuai dengan dunia kerja, sehingga barang atau jasa yang dihasilkan harus sesuai dengan tuntutan pasar atau konsumen.

Pembelajaran di DUDI melalui program PI mengacu pada prosedur dan real job. Program PI membantu siswa dalam mengembangkan kompetensi yang sudah dikuasai di sekolah. Kompetensi yang menjadi perhatian adalah pengembangan hard skills dan soft skills yang belum diajarkan di sekolah. Menurut Depdikbud (1995) terdapat empat pola yang dapat dilaksanakan dalam strategi link and match melalui praktik kerja industri/ usaha, yakni: hour release, day release, block release, atau kombinasi ketiganya. Keempat pola tersebut merupakan bentuk pengaturan waktu pembelajaran di sekolah dan DUDI. Pola hour release mengatur jam pembelajaran, day release mengatur hari secara bergantian, dan block release mengatur belajar dalam kurun waktu 1-3 bulan secara bergantian. Dengan demikian sekolah dapat memilih pola yang tepat dalam pelaksanaan PI agar pemenuhan ketercapaian SKL lulusan SMK dapat terlaksana dengan baik.

Siswa dapat memperoleh dan mengembangkan kompetensi melalui pembelajaran di industri. Pembelajaran di industri tersebut dibuktikan melalui proses pembelajaran (learning process) dan hasil pembelajaran (learning outcome) seperti yang dijelaskan oleh informan. Hasil penelitian terhadap pembelajaran di industri yang berkaitan dengan learning process dan learning outcome dapat dijabarkan dibawah ini.

\section{Penguasaan Kompetensi Dasar sebelum Mengikuti PI}

Siswa harus membekali diri dengan kompetensi dasar sesuai dengan kebutuhan DUDI. DUDI mensyaratkan kompetensi tertentu sesuai dengan kebutuhan bertujuan agar siswa mampu beradaptasi dengan lingkungan, karena pekerjaan yang bersifat continue dan real job membutuhkan kemampuan tertentu. Pada dasarnya pembelajaran di industri bersifat penguatan kompetensi yang sudah dikuasai dan sering monoton. Dengan demikian siswa yang tidak memiliki kompetensi sesuai kebutuhan DUDI akan kesulitan mengikuti kegiatan-kegiatan yang ada di DUDI.

Siswa mengikuti orientasi awal sebelum mengikuti kegiatan di DUDI. Orientasi merupakan program pertama yang diberikan DUDI agar siswa dapat beradaptasi dengan lingkungan. Selain itu, orientasi bertujuan untuk menguatkan kompetensi dan mengukur seberapa banyak kompetensi yang sudah dikuasai oleh siswa. Dengan demikian, DUDI akan memberikan porsi tugas sesuai dengan kompetensi yang dikuasai oleh siswa tersebut.

PT JMI mensyaratkan siswa minimal harus memiliki keberanian memanjat. Pada dasarnya perusahaan ISP mensyaratkan karyawan untuk bisa memanjat tower. Pekerjaan yang sering dihadapi adalah instalasi jaringan dan membutuhkan karyawan yang berani dengan ketinggian. Dalam penyelesaian kegiatan tersebut, karyawan dituntut untuk berani memanjat di tempat ketinggian. Kemampuan dan keberanian memanjat menjadi syarat utama, sehingga syarat tersebut berlaku kepada peserta magang atau PI. Walaupun pada kenyataannya ada beberapa siswa yang tidak berani memanjat, sehingga pembimbing hanya memberikan tugas sesuai dengan kemampuannya.

\section{Kegiatan Siswa saat Mengikuti Program PI}

Praktik Industri memberikan pengalaman dan peningkatan kompetensi bagi siswa. 
Aktivitas setiap hari di tempat kerja merupakan bagian dari pembelajaran untuk mendapatkan kompetensi. Di PT JMI, siswa mengikuti aktivitas indoor (dalam ruangan atau di Kantor) dan outdoor (luar ruangan). Aktivitas indoor antara lain: administrasi, program, membantu produksi voucher, membuat pemrograman web, dan database pelanggan. Sedangkan aktivitas di luar ruangan (outdoor) antara lain: instalasi jaringan, konfigurasi router atau masang kabel, perbaikan jaringan untuk pelanggan, setting mikrotik, setting radio, access point, router kecil, survei lapangan sebelum pemasangan, marketing, membagikan pamflet, dan mengikuti kegiatan kurir.

Melalui proyek yang diberikan oleh pembimbing PI dan permintaan sekolah, maka siswa tersebut mendapatkan beberapa keuntungan. Disisi lain program PI dapat membantu pengembangan diri dan prestasi siswa. Hal ini merupakan kolaborasi kompetensi untuk meningkatkan kompetensi siswa. Dengan demikian program PI dan program sekolah dapat dikolaborasikan secara bersama untuk meningkatkan prestasi dan kompetensi siswa.

Jadi, dapat disimpulkan bahwa kegiatan di tempat PI yang padat mampu meningkatkan kematangan siswa seputar DUDI. Siswa dapat menyerap ilmu dengan mengulang pekerjaan yang diberikan dan bertanya apabila ada kesulitan. Selain itu siswa dikondisikan bekerja seperti karyawan pada umumnya. Dampak positifyang ditimbulkan adalah pengalaman merasakan sendiri kondisi kerja melalui waktu yang diberikan. Oleh karena itu, program PI dapat memberikan pengalaman kerja bagi siswa untuk merasakan sendiri budaya kerja di DUDI.

\section{Pola Pembimbingan yang Dilakukan oleh Pembimbing PI}

Peranan pembimbing sangat penting selama proses pelaksanaan PI. Pembimbing bertugas untuk memberikan arahan kepada siswa, memantau kegiatan siswa, dan memberikan saran atau solusi ketika terdapat masalah yang dihadapi siswa. Pembimbing industri diambil dari karyawan perusahaan yang ahli atau berada pada master di level kompetensi.

Perlakuan pembimbing atau pimpinan JMI kepada siswa sangat baik. Pembimbing tidak membeda-bedakan antarsiswa PI. Pembimbing menempatkan pekerjaan siswa berdasarkan basic skill yang dikuasainya. Hal ini dimaksudkan untuk memudahkan siswa dalam menjalankan tugas.

Metode pembimbingan kepada siswa melalui pendampingan. Siswa didampingi dalam menjalankan tugas yang diberikan. Pendampingan tersebut dapat dilakukan oleh pembimbing atau karyawan yang membersamai siswa saat itu. Metode pembimbingan lebih mengarah pada penanganan kasus atau studi kasus. Siswa diminta terlibat langsung dalam pekerjaan. Melalui keterlibatan tersebut, siswa akan mengalami permasalahan atau kasus yang dihadapi. Dengan demikian peran pembimbing akan berfungsi sebagai pemecah kasus atau masalah tersebut. Pembimbing memberikan arahan cara mengatasi kasus tersebut agar siswa dapat mengatasinya dengan baik.

Pembimbing memberikan arahan kepada siswa ketika di lapangan. Sebelum melakukan pekerjaan, siswa mengikuti briefing terlebih dahulu. Pembimbing melibatkan siswa agar mampu menganalisa sebuah kasus dan menangani kasus tersebut.

Peran pembimbing sangat penting saat terjadi masalah di lapangan. Pembimbing harus memberikan contoh bagaimana menganalisis sebuah kasus. Seperti cuplikan wawancara di atas, pembimbing mampu mengetahui masalah yang muncul di lapangan dan cara mengatasinya. Setelah mendapat analisa dari pembimbing, siswa dapat menjalankan pekerjaan tersebut dengan tepat.

Peran pembimbing sangat penting bagi siswa dalam memperoleh kompetensi. Pembimbing harus mampu berbaur dengan siswa agar mudah dalam penerimaan materi. Dengan demikian siswa dapat dengan mudah memperoleh kompetensi dari pembimbing tersebut. Kemampuan membangun kepercayaan dan keyakinan peserta didik, peka terhadap kemampuan siswa, dan kemampuan dalam mendorong siswa untuk berfikir keras dalam memutuskan sesuatu adalah modal utama dalam menjadi mentor (Vaughan, O'Neil, \& Cameron, 2011, p. 23).

Pola pembimbingan di tempat kerja membutuhkan interaksi sosial antara siswa dengan pembimbing. Interaksi sosial tersebut terdiri dari: (a) asosiatif (kerukunan, kerja sama, sharing ilmu dan pengalaman); (b) akomodasi (mediasi); asimilasi (toleransi, menghormati, dan sikap terbuka); dan (d) akulturasi (keseragaman). Keempat komponen tersebut menjadi bagian untuk melakukan interaksi. 
Siswa dan pembimbing melakukan interaksi sosial sehingga siswa memperoleh kompetensi. Penguasaan kompetensi yang didapat siswa berkaitan dengan pengetahuan, sikap, dan keterampilan. Menurut Vygotsky (Turuk, 2008, p. 248) "The child acquires knowledge through contacts and interactions with people as the first step". Anak-anak (siswa) memperoleh kemampuan melalui kontak dan interaksi dengan seseorang pada tahapan pertama.

Pada tahapan selanjutnya, siswa akan menunjukkan atau action dengan menghadapi sebuah kasus. Siswa menghadapi kasus sesuai dengan jenis pekerjaan yang sudah dipelajari, sehingga dalam penanganan kasus tidak membutuhkan waktu yang lama. Siswa mendapatkan hasil pembelajaran setelah mengikuti beberapa training dan praktik langsung di 1apangan. Ketercapaian pembelajaran tersebut diharapkan dapat membantu dalam penguasaan kompetensi siswa.

\section{Belajar melalui Pengamatan dan Mendengarkan}

Siswa melakukan pengamatan kepada karyawan yang sedang mengerjakan pekerjaan. Siswa mengikuti semua kegiatan yang dilakukan karyawan PT JMI untuk melihat bagaimana karyawan tersebut beraktivitas. Pengamatan yang dilakukan siswa dapat memberikan kontribusi dalam penguasaan kompetensi. Selama pengamatan berlangsung, siswa dapat mendengar percakapan, aktifitas yang dilakukan karyawan, cara menghadapi pelanggan, dll. Siswa dapat menangkap fenomena yang terjadi ketika di lapangan dan halhal yang dilakukan oleh karyawan. Pembimbing memberikan tugas pengamatan terlebih dahulu kepada siswa agar mudah beradaptasi dengan lingkungan.

Tugas pertama yang diberikan oleh pembimbing kepada siswa agar dapat beradaptasi dengan lingkungan. Pengamatan yang dilakukan siswa bertujuan untuk mengetahui hal-hal apa saja yang dilakukan di tempat kerja, mulai dari persiapan, proses, sampai pascaproduksi/kegiatan. Hal ini dapat mempermudah siswa untuk memetakan alur kerja. Pemetaan kerja dapat berfungsi sebagai petunjuk teknis menyelesaikan pekerjaan. Oleh karena itu, siswa mampu menyelesaikan sebu- ah pekerjaan berdasarkan petunjuk atau guide yang sudah dibuat oleh siswa sendiri.

Siswa dapat melihat secara langsung terkait dengan proses pengerjaan tugas yang dilakukan karyawan. Melalui proses pengamatan, siswa mampu mengolah untuk menjadikan sebuah pengetahuan baru yang tidak didapat di sekolah. Pengetahuan baru akan dijadikan referensi ketika siswa melakukan praktik secara langsung di lapangan. Menurut (Choy, 2010, p. 13) Choy (2010, p.13) "observations offer the opportunities to watch other more experienced workers demonstrate new and better ways of completing task". Observasi memberikan kesempatan untuk melihat pekerja yang lebih berpengalaman yang menunjukkan cara-cara baru dan menyelesaikan tugas dengan baik.

\section{Belajar Sambil Menyelesaikan Tugas (Learning by Doing) dan Mengikuti Aktivitas Kerja}

Siswa melakukan pembelajaran melalui aktivitas dan tugas yang diberikan. Proses belajar ini sering disebut learning by doing, yaitu beraktivitas atau menyelesaikan tugas disertai dengan belajar. Siswa menerapkan hasil pengamatan yang dilakukan sebelumnya untuk menyelesaikan tugas yang diberikan. Oleh karena itu siswa beraktivitas di tempat kerja merupakan sumber belajar yang kaya akan pengetahuan yang diperlukan untuk menyelesaikan tugas.

Siswa memberikan kontribusi yang jelas di tempat kerja dengan mengikuti aktivitas setiap hari. Sedangkan aktivitas yang dilakukan siswa dapat berdampak baik dalam hasil pembelajaran. Terdapat banyak pengetahuan yang didapat siswa selama mengikuti kegiatan di industri. Pengetahuan tersebut didapat secara langsung dan nyata. Hal ini tidak didapat ditempat lain seperti di sekolah, karena hanya didapat di industri tempat siswa mengikuti kegiatan PI. Learning by doing menjadi pilihan bagi siswa untuk memperoleh kompetensi di DUDI.

Siswa mendapatkan kesempatan belajar di berbagai bidang kegiatan PT JMI. Tidak hanya kegiatan yang relevan dengan TKJ, namun siswa mendapatkan kompetensi lain seperti: marketing, cara menghadapi pelanggan, administrasi, desain dan cetak voucher, web dan database, dll. Jadi kompetensi yang dida- 
pat oleh siswa tidak hanya terfokus pada bidang TKJ.

PT JMI bergerak di bidang layanan ISP, sehingga kegiatan di tempat tersebut tidak terfokus di bagian instalasi jaringan. PT JMI membagi karyawan menjadi 3 bagian, yaitu: bidang kurir, marketing, dan teknisi. Pada bidang kurir, siswa mendapat pengetahuan terkait cara penagihan terhadap konsumen. Bidang marketing mengajarkan kepada siswa terkait menawarkan barang kepada konsumen. Bidang teknisi mengajarkan kepada siswa terkait instalasi dan perawatan jaringan. Berdasarkan fokus kegiatan dari ketiga bagaian tersebut, siswa mendapatkan banyak pengalaman yang didapat. Siswa memperoleh kompetensi baru melalui pengalaman yang didapat.

Menurut Billett (2000, p. 8) "Earlier work has demonstrated the strength of contributions to learning the knowledge required for work through everyday workplace activities". Setiap pekerjaan yang ditunjukkan sebelumnya memberikan kontribusi yang kuat dalam mempelajari pengetahuan yang dibutuhkan melalui aktifitas kerja setiap hari.

\section{Belajar melalui Pengalaman}

Siswa belajar dari pengalaman yang didapat dari orang lain. Selain itu, Dewey menyatakan bahwa pengalaman menjadi titik awal dalam proses pendidikan (Shariff \& Muhamad, 2010, p. 1365). Pembimbing selalu menceritakan pengalaman yang lalu kepada siswa ketika berbincang-bincang. Siswa mendapatkan pengetahuan baru berdasarkan pengalaman yang diceritakan oleh pembimbing. Dengan demikian siswa dapat mengambil pelajaran dan tidak mengulang kesalahan-kesalahan yang dilakukan pembimbing.

Pembimbing memberikan pembelajaran terkait cara penguasaan suatu kompetensi. Menemukan pola untuk menyelesaikan kasus membutuhkan proses panjang dan waktu yang lama. Siswa diharapkan dapat menggunakan pola tersebut tanpa harus mencari seperti yang dilakukan oleh pembimbing. Melalui pola yang didapat dari pembimbing, siswa dapat mengembangkan pola yang disesuaikan dengan pemahamannya. Pola yang dikembangkan merupakan kompetensi baru yang didapat oleh siswa di tempat kerja.

Siswa mendapatkan banyak pengalaman yang didapat ketika mengikuti program
PI. Kasus yang dihadapi dan cara menyelesaikannya merupakan pengalaman yang didapat oleh siswa. Pengalaman tersebut menjadi kunci terbentuknya sebuah kompetensi. Pengalaman menjadi faktor utama dalam mengetahui seseorang memiliki banyak atau sedikit kompetensi yang sudah dikuasai. Pengalaman tersebut menambah wawasan terkait kegiatan kerja, suasana kerja, dan hal-hal informal lainnya yang tidak didapat di bangku sekolah. Menurut Fry, Ketteridge, \& Marshall (2009, p. 42) "their learning experiences have supported students' development as individuals". Pengalaman-pengalaman yang didapat mendukung pengembangan siswa.

\section{Belajar Memecahkan Masalah}

Siswa belajar mengatasi masalah (learning in problem solving) melalui tugas yang diberikan. Masalah yang dihadapi akan menjadi pelajaran berharga bagi siswa. Masalah yang dapat diselesaikan akan menjadi pengetahuan baru bagi siswa agar dapat digunakan ketika menghadapi kasus yang serupa atau terdapat kaitan dengan masalah tersebut. Jadi, siswa dapat menemukan cara menyelesesaikan sebuah masalah dengan menghadapi sebuah kasus terlebih dahulu.

Siswa menemukan solusi untuk memecahkan sebuah masalah dan dapat menyelesaikannya dikemudian hari. Menurut Jonassen (2011, p. 241) tujuan dari belajar memecahkan masalah tidak hanya menemukan solusi setiap masalah, tetapi mampu mengenali masalah serupa dikemudian hari untuk mengurangi usaha yang diperlukan untuk memecahkan masalah transfer pada waktu tersebut. Kasus yang dihadapi oleh siswa di PT JMI sangat beragam, namun memiliki pola yang sama. Instalasi jaringan merupakan salah satu pekerjaan yang sering dilakukan di PT JMI. Setiap instalasi jaringan memiliki pola yang sama antara satu tempat dengan tempat lain, namun hanya menemukan beberapa kasus yang berbeda pada setiap tempat.

Siswa menghadapi kasus tertentu pada saat di lapangan sebelum pemasangan jaringan. Kasus yang dihadapi sangat beragam, sehingga siswa berusaha menganalisa dengan baik bagaimana mekanisme pemecahan masalah tersebut. Melalui kasus tersebut, siswa dapat belajar menangani suatu masalah atau leraning in problem solving. Dengan demikian belajar mengatasi masalah merupakan 
mekanisme untuk memperoleh sebuah kompetensi.

\section{Belajar melalui Kondisi Lingkungan Kerja}

Suasana lingkungan kerja terjadi secara natural dan berjalan secara alami berkaitan dengan produktivitas, perputaran produksi, dll. Melalui susasana tersebut, siswa berhadap dapat memperoleh pengetahuan baru. Siswa dapat memilih pengetahuan yang sesuai dengan kompetensi yang dikuasai dan dibutuhkan di tempat kerja. Siswa dapat menggunakan pengetahuan tersebut untuk di generalisasikan dan diimplementasikan di tempat lain.

Siswa merasakan secara langsung kondisi lingkungan di DUDI yang tidak terdapat di sekolah. Secara keilmuan, siswa sudah diajarkan kompetensi secara komprehensif di sekolah, namun siswa harus membutuhkan penguatan kompetensi tersebut secara mendalam di DUDI. Dampak yang ditimbulkan di lingkungan kerja sangat besar, sehingga siswa mampu merasakan bagaimana kondisi sebenarnya dilapangan. Menurut Mercer \& Clayton (2012, p. 62) mengatakan bahwa karakteristik anggota-anggota kelompok mempengaruhi tingkat kepatuhan dan menjadi sumber informasi untuk menuntun perilaku.

Siswa dapat belajar dan mendapatkan kompetensi melalui praktik di lapangan. Siswa dapat mengetahui suatu daerah dan bagaimana mekanisme untuk instalasi jaringan di daerah tersebut. Untuk mengetahui keadaan suatu daerah, siswa lebih mudah mengetahui dengan praktik langsung dilapangan. Pembimbing sering mengarahkan saat praktik tersebut, tidak pernah di teorikan terlebih dahulu.

Belajar mandiri

Siswa melakukan belajar mandiri untuk memperoleh kompetensi di tempat PI. Menurut Merriam (2001, p. 9) belajar mandiri dapat membantu mendefinisikan dan mendokumentasikan suatu kasus yang terjadi bagi orang dewasa, sehingga dapat mengembangkan kapasitas orang tersebut secara mandiri. Belajar mandiri dilakukan disaat siswa tidak mendapatkan tugas dan saat istirahat. Belajar mandiri dilakukan melalui beberapa media, antara lain: internet, media simulasi, dan membaca literatur. Siswa dapat memperoleh kompetensi setelah melakukan belajar mandiri tersebut. Hasil dari belajar mandiri akan efek- tif jika dilakukan secara berulang dan di praktikkan langsung dengan kondisi sebenarnya.

Siswa mendapatkan kompetensi berasal dari kegiatan disela-sela istirahat. Selama istirahat tersebut, siswa dapat berbincang-bincang dengan karyawan dan browsing informasi di internet. Siswa dapat mencari informasi berkaitan dengan teknis-teknis yang berkaitan dengan pekerjaan. Selain itu, ilmu yang relevan dengan kegiatan di industri dapat dengan mudah diperoleh melalui interent. Dengan demikian fasilitas internet sangat membantu siswa untuk menemukan cara atau kompetensi.

\section{Belajar secara Terus Menerus dan Diulang-ulang}

Siswa belajar secara terus menerus (continue) dan diulang-ulang. Instalasi jaringan merupakan tugas yang sering diberikan pembimbing kepada siswa, sehingga siswa mampu menyelesaikan tugas tersebut dengan tepat. Pola pekerjaan yang tidak berubah menjadikan siswa mampu mengatasi kasus demi kasus yang di hadapi. Pola pekerjaan di PT JMI bersifat continue dan cenderung sama, sehingga siswa dengan mudah mengatasi kasus dan berkolaborasi dengan karyawan lain dalam pekerjaan tersebut.

Intensitas kegiatan yang padat dan jenis pekerjaan yang cenderung sama membuat siswa lebih mudah menganalisa setiap kasus. Kegiatan yang dilakukan dari pagi sampai sore setiap hari merupakan kegiatan yang diulangulang dan bersifat continue atau terus-menerus. Siswa tidak memperoleh kesempatan untuk istirahat ketika kegiatan di PT JMI padat dan harus segera diselesaikan. Namun apabila kegiatan tidak padat, siswa dapat berbincangbincang dengan karyawan, browsing internet, atau kegiatan lainnya.

\section{Mendemonstrasikan Kompetensi}

Siswa menunjukkan atau mendemonstrasikan hasil belajar melalui ujian yang diberikan oleh pembimbing. Siswa mendapatkan soal untuk menyelesaikan sebuah simulasi kasus yang diberikan oleh pembimbing. Simulasi kasus tersebut dirancang seperti keadaan sebenarnya, sehingga siswa dapat menganalisa kasus tersebut. Kasus yang diberikan kepada siswa merupakan kasus yang sering dihadapi di lapangan. Dengan demikian hasil 
dari pembelajaran di DUDI adalah siswa dapat mendemonstrasikannya.

Siswa mengikuti program PI dengan keinginan yang kuat untuk belajar dan mengembangkan diri di DUDI. Hasil yang didapat melalui program PI adalah siswa mampu mendemonstrasikan perkembangan kognitif dalam hal pengetahuan terkait pekerjaan, perkembangan psikomotorik melalui keterampilan kerja, kemampuan menyelesaikan pekerjaan, dan sikap yang berkaitan dengan DUDI. Menurut (Sugestiyadi, 2012, p. 47) "Pendidikan Vokasi secara implisit terkandung unsur-unsur berpikir (cognitive), berbuat (psychomotor), dan rasa (affective)". Menurut Jones, Voorhess \& Paulson (National Center of Educational Statisitics, 2002, p.7) "demonstrations are the results of applying competencies. It is at this level that performance can be assessed". Demonstrasi merupakan hasil dari penerapan kompetensi dan tingkatan kinerja yang dapat dinilai. Hasil pembelajaran siswa dapat dijelaskan sebagai berikut:

\section{Hasil Belajar secara Kognitif}

Siswa memiliki kepercayaan diri terhadap pengetahuan yang didapat di DUDI. Percaya diri tinggi yang dimiliki siswa karena telah memiliki pengetahuan pekerjaan dan bagaimana menyelesaikan tugas yang diberikan, pengetahuan berkaitan dengan produk, layanan yang diberikan, dan pengetahuan berkaitan dengan sistem kerja di DUDI tersebut. Hal ini dapat dilihat ketika siswa berhadapan dengan pelanggan dan menjelaskan produk dari PT JMI. Siswa mampu menjelaskan produk tersebut agar pelanggan dapat membeli produk dari PT JMI. Selain itu, siswa dapat menyelesaikan kasus yang dihadapi di lapangan. Kasus yang dihadapi memerlukan pengetahuan yang komplek agar dapat terpecahkan.

PI memberikan gambaran berkaitan dengan keadaan nyata di dunia kerja. Siswa mendapatkan pengalaman secara langsung bagaimana orang bekerja, suka dan dukanya bekerja, dll. Pengetahuan tersebut menjadi faktor utama dalam menumbuhkan semangat bekerja dan menjadi faktor penentu kedewasaan seseorang, sehingga seseorang mampu beradaptasi dengan lingkungan.

Peningkatan kemampuan pada ranah kognitif ini sesuai teori yang dikembangkan oleh Piaget bahwa faktor yang sangat mempengaruhi perkembangan kognitif terdiri dari pengalaman fisik dan sosial. Pengalaman fisik yaitu interaksi manusia dengan lingkungannya, sedangkan sosial yaitu kerja sama yang dilakukan oleh manusia dengan orang lain.

\section{Hasil Belajar secara Afektif}

Siswa mampu menanam sikap-sikap positif ketika mendapatkan tugas atau pekerjaan. Sikap positif tersebut antara lain: sabar, berfikir positif, ketekunan, dll. Sikap tersebut tertanam pada siswa setelah merasakan beberapa hal yang ada didalam industri. Sebagai contoh adalah sikap ikhlas dalam melaksanakan tugas dapat mempengaruhi hasil praktik.

Siswa telah meningkatkan kompetensi dalam ranah afektif setelah mengikuti program PI di DUDI. Peningkatan tersebut antara lain: kerja dalam tim, sabar, berfikir positif, ketekunan, manajemen waktu, tanggung jawab, kedewasaan, kemampuan bekerja di bawah tekanan, mendengarkan dan menghargai pembicaraan orang. Dengan demikian siswa dapat membuat pola hidup atau membentuk karakter setelah mengikuti program PI.

\section{Hasil Belajar secara Psikomotorik}

Siswa memiliki keterampilan yang dibutuhkan di PT JMI. Siswa mampu menunjukkan keterampilan tersebut ketika mendapatkan tugas instalasi jaringan, setting peralatan jaringan, maintenance jaringan, pembuatan web dan database pelanggan, dan keterampilan lainnya. Siswa dapat juga menunjukkan hasil yang didapat setelah mengikuti praktik dengan menyelesaikan soal dalam bentuk kasus yang diberikan oleh pembimbing.

Setelah mengikuti program PI di PT JMI, siswa telah meningkatkan dan mampu memenuhi keterampilan jaringan yang dibutuhkan industri. Keterampilan siswa mengalami peningkatan jika dibandingkan dengan keterampilan sebelum mengikuti PI. Selain itu siswa mampu menyelesaikan dengan baik UPK tersebut karena soal yang diberikan merupakan pekerjaan yang pernah di lakukan di DUDI. Dengan demikian kebermanfaatan PI dapat dirasakan bagi siswa setelah menyelesaikan program PI, khususnya saat UPK di sekolah dan umumnya keterlibatan di masyarakat.

Siswa dapat menunjukkan hasil belajar secara psikomotorik berupa jasa instalasi dan perawatan jaringan. Instalasi dan perawatan 
jaringan merupakan pekerjaan pokok di PT JMI. Selain itu merupakan bagian dari SKL Program Keahlian TKJ yang harus dikuasai oleh siswa.

\section{Mengevaluasi Peningkatan Kompetensi Siswa}

Bentuk evaluasi yang diterapkan di PT JMI adalah tes simulasi. Tes tersebut merupakan simulasi penanganan kasus seperti keadaan di lapangan. Soal yang diberikan merupakan pengembangan dari materi yang sudah di praktikkan oleh siswa. Setting jaringan merupakan materi yang diujikan kepada siswa. Selain setting jaringan, siswa dihadapkan dengan soal men-setting router untuk mengetahui kemampuan analisa jaringan.

Setting jaringan merupakan kompetensi yang harus dikuasai oleh siswa program keahlian TKJ. Setting jaringan menjadi komponen wajib yang harus dikuasai siswa, karena apabila dapat menguasai kompetensi tersebut siswa dapat mengatasi permasalahan yang lain. Semua kegiatan yang berkaitan dengan jaringan pasti memerlukan setting jaringan. Dengan demikian siswa harus mampu menguasai setting jaringan tersebut. Komponen tersebut antara lain: setting radio dan setting router. Kedua komponen tersebut wajib dikuasai oleh siswa dalam pemenuhan kompetensi TKJ.

Siswa harus menyelesaikan kasus pengembangan yang belum dihadapi saat praktik. Siswa harus mampu memadukan beberapa teori dan pengalaman lapangan agar dapat memecahkan masalah yang diberikan oleh pembimbing. Siswa selalu melakukan setting alat tersebut saat menyelesaikan tugas instalasi. Perbedaan setting router dengan setting pemancar hanya terletak pada langkah-langkah yang dilakukan. Dengan demikian siswa harus berfikir kritis agar dapat menemukan langkah yang tepat untuk setting router.

\section{Mengevaluasi Peningkatan Kompetensi Siswa}

Bentuk evaluasi yang diterapkan di PT JMI adalah tes simulasi. Tes tersebut merupakan simulasi penanganan kasus seperti keadaan di lapangan. Soal yang diberikan merupakan pengembangan dari materi yang sudah di praktikkan oleh siswa. Setting jaringan merupakan materi yang diujikan kepada siswa. Selain setting jaringan, siswa dihadapkan de- ngan soal men-setting router untuk mengetahui kemampuan analisa jaringan.

Setting jaringan merupakan kompetensi yang harus dikuasai oleh siswa program keahlian TKJ. Setting jaringan menjadi komponen wajib yang harus dikuasai siswa, karena apabila dapat menguasai kompetensi tersebut siswa dapat mengatasi permasalahan yang lain. Semua kegiatan yang berkaitan dengan jaringan pasti memerlukan setting jaringan. Dengan demikian siswa harus mampu menguasai setting jaringan tersebut. Komponen tersebut antara lain: setting radio dan setting router. Kedua komponen tersebut wajib dikuasai oleh siswa dalam pemenuhan kompetensi TKJ.

Siswa harus menyelesaikan kasus pengembangan yang belum dihadapi saat praktik. Siswa harus mampu memadukan beberapa teori dan pengalaman lapangan agar dapat memecahkan masalah yang diberikan oleh pembimbing. Siswa selalu melakukan setting alat tersebut saat menyelesaikan tugas instalasi. Perbedaan setting router dengan setting pemancar hanya terletak pada langkah-langkah yang dilakukan. Dengan demikian siswa harus berfikir kritis agar dapat menemukan langkah yang tepat untuk setting router.

\section{Hirarki Pembelajaran melalui Program PI}

Hasil penelitian menunjukkan pelaksanaan PI sangat efektif untuk meningkatkan kompetensi siswa. Siswa mendapatkan kompetensi baru yang tidak didapat di sekolah. Pada dasarnya program PI merupakan bagian dari link and match yang memadukan pembelajaran di sekolah dan industri. Pembelajaran di sekolah lebih condong pada penguatan kompetensi dasar dan beberapa kompetensi yang mampu diterapkan. Sedangkan pembelajaran di industri lebih kepada kompetensi praktis dan kondisi secara nyata di lapangan. Kedua komponen tersebut saling terkait satu sama lain dan mampu berkolaborasi dengan baik apabila diterapkan secara maksimal.

DUDI membutuhkan kompetensi tertentu dalam aktivitas kerja dan pemenuhan kebutuhan. Menurut Gangani, McLean, \& Braden (2006) kompetensi yang dibutuhkan oleh DUDI dibagi menjadi tiga kelompok, yaitu: fundamental competencies, functional competencies, dan personal competencies. Fundamental competencies yaitu kompetensi 
yang harus dimiliki karyawan pada semua bidang pekerjaan. Functional competencies yaitu kompetensi untuk membantu beberapa aktivitas pekerjaan tertentu secara efektif. Personal competencies yaitu kompetensi untuk membantu karyawan dalam pencapaian individu dan level lebih tinggi.

Ketiga kompetensi di atas dapat diperoleh melalui proses pembelajaran dalam program PI. Proses dan hasil pembelajaran tersebut digambarkan dalam bentuk hirarki seperti pada Gambar 2.

Hirarki proses dan hasil perolehan kompetensi merupakan pengembangan dari $a$ hierarchy of postsecondary outcomes dari dari Jones, Voorhees, \& Paulson (2002, p.8) yang tidak menjelaskan bentuk foundation: traits and characters dan experience learning process. Terdapat 4 bagian didalam hirarki tersebut untuk menjelaskan proses dan hasil pembelajaran yang dilakukan di industri melalui program PI. Keempat bagian tersebut antara lain: kompetensi dasar, proses pembelajaran, kompetensi, dan demonstrasi. Keempat bagian tersebut selanjutnya dilakukan evaluasi dan assesment (penilaian) pada setiap tahapannya. Tujuannya adalah untuk mengukur seberapa tinggi kemampuan individu dalam ketercapaian kompetensi. Berikut adalah penjabaran dari keempat komponen tersebut, yaitu:

Pertama, kompetensi dasar merupakan pondasi dasar yang dimiliki oleh setiap siswa. Selain itu merupakan pengembangan dari keterampilan dasar yang dikemukakan oleh (Stern, 2003). Pada kompetensi dasar, siswa memiliki: (1) sifat bawaan, sikap, dan karakter; (2) keterampilan dasar (mendengarkan, membaca, menulis, berbicara, matematika/ menghitung); (3) keterampilan berfikir (cara belajar, berkarya, penyelesaian masalah, membuat keputusan); (4) personal quality (tanggung jawab, integritas, percaya diri, moral, karakter, loyalitas); dan (5) disiplin ilmu kejuruan. Berdasarkan hasil penelitian, maka disiplin ilmu kejuruan dimasukkan sebagai pondasi dasar.

Kedua, proses pembelajaran terdapat unsur keterampilan, kemampuan dan pengetahuan yang dikembangkan melalui proses pembelajaran. Terdapat beberapa proses pembelajaran yang dilakukan oleh siswa, yaitu: (1) melalui pengamatan dan mendengarkan; (2) belajar sambil menyelesaikan tugas (learning by doing) dan mengikuti aktivitas kerja;
(3) belajar melalui pengalaman; (4) belajar memecahkan masalah; (5) belajar melalui kondisi lingkungan kerja; (6) belajar mandiri; dan (7) belajar secara terus menerus dan diulang-ulang.

Ketiga, kompetensi merupakan hasil dari pengalaman yang didapat melalui pembelajaran di industri. Kompetensi tersebut berfungsi untuk menyelesaikan tugas atau mengikuti aktivitas tertentu.

Keempat, demonstrasi atau menunjukkan kompetensi yang sudah didapat dengan menerapkannya. Demonstrasi yang dilakukan oleh siswa dapat dinilai secara langsung. Dengan demikian penilaian kinerja dilakukan pada tahapan ini untuk mengukur kompetensi yang dikuasai oleh siswa, sehingga hasil dari pengukuran tersebut dapat dievaluasai.

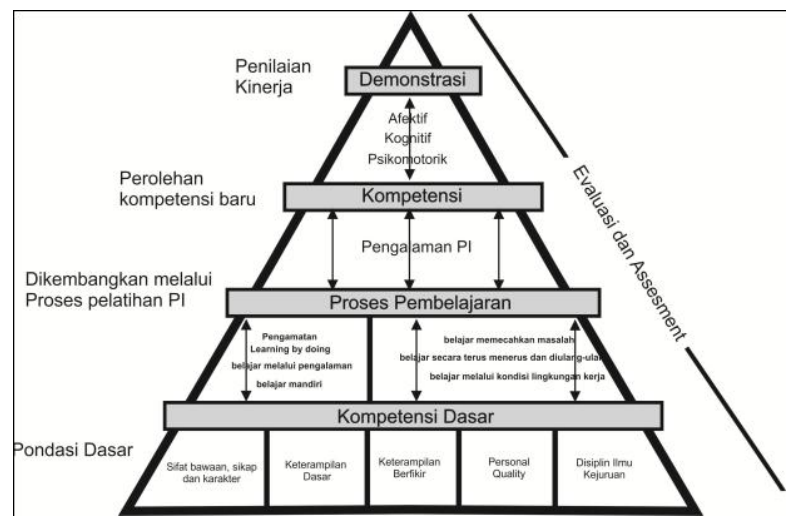

Gambar 2. Hirarki Proses dan Hasil Perolehan Kompetensi melalui PI

\section{SIMPULAN}

Siswa harus membekali diri dengan kompetensi dasar sesuai dengan kebutuhan DUDI. DUDI mensyaratkan kompetensi tertentu sesuai dengan kebutuhan bertujuan agar siswa mampu beradaptasi dengan lingkungan, karena pekerjaan yang bersifat continue dan real job membutuhkan kemampuan tertentu. Pada dasarnya pembelajaran di industri bersifat penguatan kompetensi yang sudah dikuasai dan sering monoton. Dengan demikian siswa yang tidak memiliki kompetensi sesuai kebutuhan DUDI akan kesulitan mengikuti kegiatan-kegiatan yang ada di DUDI.

Praktik Industri memberikan pengalaman dan peningkatan kompetensi bagi siswa. Aktivitas setiap hari di tempat kerja merupakan bagian dari pembelajaran untuk mendapatkan kompetensi. Di PT JMI, siswa mengikuti aktivitas indoor (dalam ruangan atau di 
kantor) dan outdoor (luar ruangan). Aktivitas indoor antara lain: administrasi, program, membantu produksi voucher, membuat pemrograman web, dan database pelanggan. Sedangkan aktivitas di luar ruangan (outdoor) antara lain: instalasi jaringan, konfigurasi router atau masang kabel, perbaikan jaringan untuk pelanggan, setting mikrotik, setting radio, access point, router kecil, survei lapangan sebelum pemasangan, marketing, membagikan pamflet, dan mengikuti kegiatan kurir.

Metode pembimbingan kepada siswa melalui pendampingan. Siswa didampingi dalam menjalankan tugas yang diberikan. Pendampingan tersebut dapat dilakukan oleh pembimbing atau karyawan yang membersamai siswa saat itu. Metode pembimbingan lebih mengarah pada penanganan kasus atau studi kasus. Siswa diminta terlibat langsung dalam pekerjaan. Melalui keterlibatan tersebut, siswa akan mengalami permasalahan atau kasus yang dihadapi. Dengan demikian peran pembimbing akan berfungsi sebagai pemecah kasus atau masalah tersebut. Pembimbing memberikan arahan cara mengatasi kasus tersebut agar siswa dapat mengatasinya dengan baik.

Siswa melalui beberapa proses untuk memperoleh kompetensi di tempat industri. Proses tersebut antara lain: (1) melalui pengamatan dan mendengarkan; (2) belajar sambil menyelesaikan tugas (learning by doing) dan mengikuti aktivitas kerja; (3) belajar melalui pengalaman; (4) belajar memecahkan masalah; (5) belajar melalui kondisi lingkungan kerja; (6) belajar mandiri; dan (7) belajar secara terus menerus dan diulang-ulang. Ketujuh proses tersebut dilalui oleh siswa untuk mendapatkan kompetensi baru.

Siswa mengalami proses yang panjang selama di DUDI untuk mendapatkan kompetensi. Siswa mengikuti program PI menunjukkan hasil belajar dengan cara menyelesaikan tugas yang diberikan. Siswa mampu menunjukkan perkembangan kognitif, afektif, dan psikomotorik yang dapat dideskripsikan antara lain: pengetahuan terkait dunia kerja, keterampilan kerja, kemampuan menyelesaikan pekerjaan, dan sikap yang berkaitan dengan DUDI.

Bentuk evaluasi yang diterapkan di PT JMI adalah tes simulasi. Tes tersebut merupakan simulasi penanganan kasus seperti keadaan di lapangan. Soal yang diberikan merupakan pengembangan dari materi yang sudah di praktikkan oleh siswa. Setting jaringan merupakan materi yang diujikan kepada siswa. Selain setting jaringan, siswa dihadapkan dengan soal men-setting router untuk mengetahui kemampuan analisa jaringan.

Pada dasarnya siswa mendapatkan soal men-setting komponen yang ada didalam jaringan. Komponen tersebut antara lain: setting radio dan setting router. Kedua komponen tersebut wajib dikuasai oleh siswa dalam pemenuhan kompetensi TKJ. Siswa harus mampu memadukan beberapa teori dan pengalaman lapangan agar dapat memecahkan masalah yang diberikan oleh pembimbing. Siswa selalu melakukan setting alat tersebut saat menyelesaikan tugas instalasi. Perbedaan setting router dengan setting pemancar hanya terletak pada langkah-langkah yang dilakukan. Dengan demikian siswa harus berfikir kritis agar dapat menemukan langkah yang tepat untuk setting router.

\section{Implikasi}

Pembelajaran di sekolah dan di DUDI memerlukan sinergitas agar target SKL dapat terpenuhi. Pembagian beban materi yang diajarkan memerlukan perancangan bersama dalam membangun kompetensi siswa. Siswa SMK tidak dapat belajar hanya di bangku sekolah saja, namun diimbangi dengan pembelajaran di DUDI. Siswa mendapatkan kompetensi dasar yang di ajarkan di sekolah dan dikembangkan kompetensi tersebut di DUDI. Sinergitas antara sekolah dan DUDI diharapkan dapat memenuhi SKL yang sudah dirancang oleh Pemerintah.

Ketercapaian pembelajaran membutuhkan fasilitas yang memadahi dan didukung oleh instruktur yang berpengalaman. Siswa dapat mengamati dengan baik setiap pekerjaan yang dilakukan oleh instruktur tersebut. Melalui proses pengamatan, siswa mampu menguasai kompetensi dasar dan dapat digunakan sebagai dasar untuk melakukan pekerjaan tertentu.

Kegiatan PI harus memberikan ruang kepada siswa untuk mengembangkan diri. Siswa dapat belajar sambil bekerja (learning by doing) agar kompetensi dapat terserap dengan baik dan maksimal. Fasilitas yang diberikan harus sesuai dengan kebutuhan kompetensi untuk memenuhi SKL yang sudah ditetapkan. Dengan demikian, ketercapaian pembelajaran 
dapat terpenuhi dengan pemenuhan fasilitas dan instruktur yang berpengalaman.

\section{Saran}

Berdasarkan hasil penelitian tentang proses perolehan kompetensi Pada Program PI, maka terdapat beberapa saran yang dapat dipakai sebagai bahan pertimbangan untuk membuat kebijakan berkaitan dengan PI, yaitu sebagai berikut.

Pertama, kepada unsur pimpinan dan manajemen DUDI untuk memperhatikan proses pembelajaran PI tersebut. Program PI dapat menjadi titik awal siswa memperoleh kompetensi dan mendapatkan pengalaman yang berharga. Hal ini sebenarnya dapat menguntungkan bagi pihak DUDI, karena tidak perlu mentraining kembali siswa setelah lulus. Pimpinan DUDI harus merancang kurikulum yang terstruktur agar proses pembelajaran dapat dimonitoring dan dievaluasi. Pimpinan DUDI dapat melihat pola pembelajaran yang dilakukan siswa selama mengikuti kegiatan PI, sehingga dapat dengan mudah menemukan pola yang akan dirumuskan menjadi kurikulum pembelajaran di DUDI.

Kedua, kepada pihak smk agar memberikan standar minimal waktu PI, sehingga siswa dapat dengan mudah menyerap kompetensi di DUDI dengan maksimal. Proses perolehan kompetensi yang dilakukan siswa membutuhkan waktu yang tidak pendek. Penyerapan kompetensi melalui berbagai kegiatan yang berulang-ulang menjadikan siswa mampu memecahkan masalah dengan cepat. Waktu pelaksanaan PI minimal selama 3 bulan adalah ideal.

Ketiga, siswa mengalami kendala persiapan menjelang ujian nasional (UN) ketika PI di kelas XII. Hal ini mengakibatkan persiapan menjelang UN hanya efektif sekitar 3 bulan. Dengan demikian, waktu pelaksanaan PI yang efektif adalah saat kelas XI. Kelas XI pada semester 2 merupakan waktu yang tepat untuk melaksanakan PI, sehingga ketika siswa masuk ke kelas XII lebih fokus kepada persiapan UN.

\section{DAFTAR PUSTAKA}

BBPP Batangkaluku. (2013). Analisa kepuasan peserta terhadap pelayanan penyelenggaraan pelatihan. Retrieved March 20, 2015, from http://bbpp- batangkaluku.com/bbpp/index.php/allcategory/90-kajiwidya/197-kw10

Billett, S. (2000). Guided learning at work. Journal of Workplace Learning, 12(7), 272-285. https://doi.org/10.1108/13665620010353 351

Bukit, M. (2002). Beberapa masalah dalam implementasi pendidikan sistem ganda di SMK. In D. Supriadi (Ed.), Sejarah pendidikan teknik dan kejuruan di Indonesia, membangun manusia produktif, Dirdikmenjur Depdiknas (pp. 527-542). Bandung: Rosdakarya.

Catts, R., Falk, I., \& Wallace, R. (2011). Introduction: Innovations in theory and practice. In R. Catts, I. Falk, \& R. Wallace (Eds.), Vocational learning innovative theory and practice (pp. 1-8). New York: Springer.

Choy, S. C. (2010). Students' conceptual knowledge about workplace pedagogies and applications to learning in the workplace. In Proceedings of Australian Vocational Education and Training Research Association (AVETRA). April 8-9, 2010, Gold Coast.

Djojonegoro, W. (1998). Pengembangan sumberdaya manusia melalui sekolah menengah kejuruan (SMK). Jakarta: PT Balai Pustaka.

Emzir. (2010). Metode penelitian kualitatif: analisis data. Jakarta: Rajawali Pers.

Fry, H., Ketteridge, S., \& Marshall, S. (2009). A handbook for teaching and learning in higher education: Enhancing academic practice (3rd ed.). London: Routledge.

Gangani, N., McLean, G. N., \& Braden, R. A. (2006). A Competency-Based Human Resource Development Strategy. Performance Improvement Quarterly, 19(1), 127-139. https://doi.org/10.1111/j.19378327.2006.tb00361.x

Hardum, S. E. (2015, March 6). Kemnaker targetkan kirim 2.000 peserta magang ke Jepang. Beita Satu. Retrieved from http://www.beritasatu.com/nusantara/254 393-kemnaker-targetkan-kirim-2000peserta-magang-ke-jepang.html

Jonassen, D. H. (2011). Learning to solve problems: A handbook for designing 
problem-solving learning environments. New York: Routledge.

Jones, E., Voorhees, R., \& Paulson, K. (2002). Defining and assessing learning: Exploring competency-based initiatives. Washington, DC: Council of the National Postsecondary Education Cooperative. Publication NCES 2002159. Diambil pada tanggal 19 April 2015 dari http://nces.ed.gov/pubs2002/2002159.pdf

Majid, N. W. A. (2015). Pola pembimbingan di tempat kerja: studi kasus pelaksanaan program praktik industri di PT JMI. Jurnal Taman Vokasi, 3(2), 761-768.

Mercer, J., \& Clayton, D. (2012). Psikologi sosial. (Terjemahan Noermalasari Fajar Widuri). New York: Pearson Education Ltd.

Merriam, S. B. (2001). New directions for adult and continuing education. San Francisco: John Wiley \& Sons, Inc.

Miles, M. B., Huberman, A. M., \& Saldana, J. (2014). Qualitative data analysis: a methods sourcebook. New York: SAGE Publications, Inc.

Miswardi, Y., \& Pardjono, P. (2013). Proses dan hasil belajar pada prakerind bidang keahlian kendaraan ringan: studi kasus pada industri pasangan smkn 3 yogyakarta. Jurnal Pendidikan Vokasi, 3(2). Retrieved from http://journal.uny.ac.id/index.php/jpv/arti cle/view/1606/1339

Muliati. (2008). Evaluasi pendidikan sistem ganda (Suatu penelitian evaluatif berdasarkan Stake's countenance model mengenai program pendidikan sistem ganda pada sebuah SMK di Sulawesi Selatan (2005/2007). Ringkasan Disertasi, Universitas Negeri Jakarta.

Pardjono. (2011). Peran industri dalam pengembangan SMK. In Workshop peran industri dalam pengembangan SMK di SMKN 2 Kasihan Bantul.

Shariff, S. M., \& Muhamad, M. (2010). Learning in an industrial practicum training program: a case study in a public university in malaysia. World Applied Sciences Journal, 11(11), 1361-1368. Retrieved https://www.idosi.org/wasj/wasj11(11)/8. pdf

Singh, M. (2009). Social and cultural aspects of informal sector learning: meeting the goals of EFA. In R. Maclean, D. Wilson, \& C. Chinien (Eds.), International handbook of education for the changing world of work, bridging academic and vocational learning (pp. 349-358). Bonn: Springer.

Stern, B. (2003). Career and workforce development trends: implication for Michigan higher education white paper. Michigan: Ferris State University.

Sugestiyadi, B. (2012). Model magang siswa sekolah menengah kejuruan (SMK) bidang teknik furniture di Jawa Tengah. Disertasi, tidak dipublikasikan. Universitas Negeri Yogyakarta.

Suwarman, \& Pardjono. (2014). Pengelolaan praktik kerja industri pada program keahlian teknik pemesinan smk sekabupaten kulon progo. Jurnal Pendidikan Vokasi, 4(1), 83-95. Retrieved from http://journal.uny.ac.id/index.php/jpv/arti cle/view/2537/2095

Turuk, M. C. (2008). The relevance and implications of vygotsky's sociocultural theory in the second language classroom. The Annual Review of Education, Communication, and Language Sciences Is an Electronic (ARECLS) Journal, 5(1), 244-262. Retrieved from http://research.ncl.ac.uk/ARECLS/vol5_ documents/Articles/turuk_vol5.pdf

Vaughan, K., O’Neil, P., \& Cameron, M. (2011). Successful workplace learning: how learning happens at work. Industry Training Federation: Industry Training Federation. Retrieved from http://www.nzcer.org.nz/research/publica tions/successful-workplace-learninghow-learning-happens-work

Wallace, R. (2011). Social partnerships in learning: connecting to the learner identities of disenfranchised regional learners. In R. Catts, I. Falk, \& R. Wallace (Eds.), Vocational Learning Innovative Theory and Practice (pp. 931). New York: Springer. 